Article

\title{
Social Justice and Lower Attainers in a Global Knowledge Economy
}

Sally Tomlinson

Department of Education, University of Oxford, 15 Norham Gardens, Oxford OX2 6PY, UK; E-Mail: s@stomlinson.net; Tel.: +441386859317

\section{How to Cite this Article}

Tomlinson, S. (2013). Social Justice and Lower Attainers in a Global Knowledge Economy. Social Inclusion, 1(2), $102-112$.

\section{Acknowledgement}

This Article was published by Librello, Social Inclusion's former publisher.

\section{About the Journal}

Social Inclusion is a peer-reviewed open access journal which provides academics and policy-makers with a forum to discuss and promote a more socially inclusive society. The journal encourages researchers to publish their results on topics concerning social and cultural cohesiveness, marginalized social groups, social stratification, minority-majority interaction, cultural diversity, national identity, and core-periphery relations, while making significant contributions to the understanding and enhancement of social inclusion worldwide.

www.cogitatiopress.com/socialinclusion

\section{Editor-in-Chief}

Professor UIf R. Hedetoft, Faculty of Humanities, University of Copenhagen, Denmark

\section{Managing Editor}

Mr. António Vieira, Social Inclusion, Cogitatio Press, Portugal 


\title{
Social Justice and Lower Attainers in a Global Knowledge Economy
}

\author{
Sally Tomlinson \\ Department of Education, University of Oxford, 15 Norham Gardens, Oxford OX2 6PY, UK; \\ E-Mail: s@stomlinson.net; Tel.: +44 1386859317
}

Submitted: 16 June 2013 | In revised form: 30 September 2013 | Accepted: 24 October 2013 |

Published: 11 November 2013

\begin{abstract}
National governments believe that higher levels of educational attainments and training are necessary for successful competition in knowledge-driven economies and all young people are urged to invest in their own human capital and learn new skills. Moves towards inclusive education have brought into mainstream schools and colleges many who would formerly have been segregated in special schooling or otherwise given minimum education, joining those simply regarded as lower attainers. More research is needed on what is happening to all these young people who do not do well in competitive education systems and uncertain job markets. This article is taken from a study which set out to discuss with school and college principals, local administrators, teachers and others, who they regard as lower attainers, what sort of education and training programmes are offered to the students, and what policies they think are in place to help young people into work or independent living. Discussions were held with respondents in England, Germany, the USA, Finland and Malta. The article takes Rawls' view that social injustice is mainly due to the inequitable distribution of economic and social resources and the State has a responsibility to ensure that all young people can participate in the economy and the society.
\end{abstract}

Keywords: global economy; low attainment; special educational needs; vocational training

\section{Introduction}

The past thirty years have seen a widespread acceptance of beliefs that all citizens in nation-states are subject to the forces of globalisation and global economic markets. National governments believe that higher levels of education and skills training are necessary for successful competition in knowledge-driven economies, and all young people are urged to invest in their own human capital and constantly learn new skills, competing with each other in stratified education systems and uncertain job markets. While transitions from schooling into labour markets have been a focus for policy concern across OECD countries over the past thirty years [1], and are of particular concern to the European Commission [2], moves from education/training into work have become more complex as education systems have expanded and drawn in groups previously 
excluded or given only minimal schooling, and labour markets for all young people have become more hazardous. Youth unemployment in developed countries continues to grow, with those aged 15-24 three times more likely than adults to be unemployed, and the largest rise being those who are variously regarded as lower attainers, have learning difficulties, and/or have acquired labels of disability or special educational need. While there has been a focus on raising attainment levels of all lower attainers, with or without designated special educational needs ([3], see for example [4] and the journal Inclusive Education; see also the Appendix), how they are to be included in national economies is unclear, but they are likely to be included, if at all, in a low-skill, low-wage sector (see for example $[5,6])$. The necessity for the inclusion of all young people in the economy and society in times of economic crisis is a matter of social justice as well as economic necessity, and despite stated government policies exclusion and marginalisation continues to take place. This article is taken from a study funded by the Leverhulme Trust, which aimed to explore in more detail what is happening to young people post 14-16 who are defined as lower attainers, having learning difficulties, or have acquired special education labels in a global knowledge economy [7,8]. While policy, practice and literature on the expansion and provision for those regarded simply as lower attainers, those designated as in need of some form of special education, and their vocational education and training has largely remained separate, in this study they were deliberately brought together. It was apparent from the 1980s that an expansion of 'special' education was linked to the question as to what kind of education and training should be offered to all those who found difficulty in learning in education systems largely designed to produce academic and technical groups, especially in countries where vocational education was poorly developed. By the 1990s a world-wide move towards inclusive education meant that mainstream schools and vocational colleges began to incorporate a range of students who have learning difficulties and disabilities, joining those who previously were simply designated as lower attainers. All young people are expected to participate post 14-16 in some form of education and training for a potential working future, or failing that, be prepared for independent living.

\section{Expanded Education}

State education systems, comprising nation-wide collections of institutions and personnel devoted to formal education and training, are, in developed countries, enormous in size and complexity and enormously expensive. Education is part of a large global industry and what is regarded as valuable knowledge can be bought and sold via state and private agencies. In emerging states, from the nineteenth century, state education "embodied a new universalism which acknowledged that education was applicable to all groups in society and could serve a variety of social needs" ([9], p. 79), but it usually served the interests of dominant classes. As Judt pointed out, in Europe up to the 1950s, most children left school at 12 or 14, the grammar schools, lyceums and gymnasiums, with their classical curricula, being "the preserve of a ruling elite" [10]. Some countries, notably Germany, early on developed a system where it was possible for good vocational training to be offered to a majority of young people and respect for the Beruf (trade or occupation) included the notion of full development of each person. Other countries, notably England, with an Education Minister in 1902 who had a 'particular loathing for vocational and technical education' [11-13] and an Education Minister in 2010 who decided that vocational subjects studied in school should not be counted as 'equivalent' to academic subjects, have not been so successful in creating a system in which all can participate with fair access, and resources [11-13].

A further justification for educational expansion centred around the social control of groups of young people who were likely to be potentially disruptive to the society through delinquency and possible criminality. While ideologies of humanitarianism and vested interest still provide a framework for most professionals, public attitudes towards potentially workless lower attainers have become increasingly punitive. In England workless youth are labelled as 'chavs, yobs or scroungers' $[14,15]$ and increasing inequality in society has fostered resentments. Attempts to use education to create more cohesive societies usually founder on the contradiction that mass education systems were never oriented towards the common good, but developed from sectional social, political and religious interests, often in competition with each other, which has the effect of dividing groups, notably by social class and ethnicity, rather than creating cohesion.

While lower attainers and a majority of those deemed to require special education were historically mainly from the working classes, with an over-representation of immigrant and ethnic minorities in the more stigmatised categories, from the 1990s there has been an expansion of middle class demands for recognition and resources for their children who have difficulty in learning in competitive school environments. Parents are driven by anxieties that with constantly raised qualification levels and intense competitive environments their 'less-able' children will be unable to find or keep paid work, although middle-class parents are still likely to avoid placement of their children on vocational courses. It is the case that the expansion of education systems has led to an expansion of institutional arrangements for all these lower attaining young people, and the whole edifice of mass education in a global economy is now underpinned by expansion for lower achievers and those with learning difficulties or disabilities [16]. 


\section{The Research Study}

Given that national governments offer a range of vocational education and training policies and there are European-wide efforts to improve the education and skills agenda, including focusing on low achievers in basic skills, this qualitative study was intended to gather information on the views and practices of a selection of personnel who, while not policy-makers, actually carry out the educational and vocational arrangements for lower attainers post-14 and 16 in mainstream and special schools and colleges [17]. Information on policy and practice was initially sought by visiting schools, colleges and administrators in three English local authorities. To collect some comparative information on similarities and differences in what was offered to low achievers and 'special' students in other countries, visits were made in the USA (New York and Los Angeles), Germany (North Rhine Westphalia), Malta and Finland. It was not intended to provide rigorous case studies, but to consider differences in practice between what is now a highly centralised English system, a smaller centralised system in Malta, two areas largely decentralised in federal state organisation, New York and Los Angeles in the USA, North Rhine Westphalia in Germany, and a smaller decentralised state, Finland. Despite the USA, UK and Malta being dominated by neo-liberal market governance, with Germany and Finland more inclined towards democratic welfare governance, in all the countries there is no clear definition of 'lower attainer', with or without special needs or a disability. Definitions vary at different historical periods, between different countries, and between professionals and practitioners tasked with discovering and dealing with those who cannot or will not achieve well in current education systems [18]. Who gets defined as a lower attainer or disabled depends on what currently constitutes adequate attainment and normality in the society at any given time. In this study however, it was clear that lower attainers in all the countries are affected by beliefs that there is a global knowledge economy, in which they are unlikely to participate. In the market economies it was more likely that individual lower attainers and their families would be regarded as deficient in a variety of ways, whereas in more social democratic regimes there was more focus on the labour market and its deficiencies rather than blaming the young people as unprepared for work. The respondents in this study thought that it was the structure of economies and whether jobs were available that was as important as qualifications for lower attainers, and while there is an expanding literature on polarising labour markets, with an increased demand for higher level skills and a diminished demand for lower level work, the labour market position of the lower skilled may be deteriorating [19].

Some seventy-seven face-to-face 'discussions' were held in the five countries, with school and College
Principals, teachers, administrators, careers advisors and others, and there was some limited observation of students [20]. The three questions in the discussions centred around: what is happening to young people in developed countries who are regarded as lower achievers, have learning difficulties or special needs, and how are they currently defined? How have education systems expanded to take account of these young people and what sort of education and training systems are in place for them? What is the relationship between the development of a global economy and a knowledge economy and what is the place of lower attainers in this economy? Theoretical considerations on which the study was based were concerned with political economy-the study of the production, distribution and consumption of wealth and how this affects young people, and with understanding the expansion of education systems in modern capitalist nation-states to include lower attaining groups, and the links to social class, race and ethnicity. Current political ideology in many countries stresses the individual's contribution to wealth creation, especially via the participation of young people, but does not necessarily prepare them properly to participate or endeavour to regulate the economy in ways that will actually employ their labour and share out the wealth produced more fairly. This leads on to a consideration of social justice claims that all young people should be included in the economic, social and political institutions in a society. Rawls, whose Theory of Justice [21] has had much influence on redistributive theories, affirmative action and welfare programmes, took the view that since social injustice was mainly the result of the inequitable distribution of economic, social and political goods and resources, the State had a responsibility to create rules and programmes aimed at removing barriers arising from unequal power relations, and to provide 'equity, access and participation' for all. In countries embracing competitive neo-liberal market beliefs, there is a particular contradiction between a rhetoric of social and economic inclusion and the realities of divisiveness and injustice.

\section{England: Lower Attainers as Social Problems}

In England historical definitions of lower attainerslabelled early on as defective, feeble-minded, dull, retarded-were based on beliefs in the biological and cultural inferiority of lower social classes and racial groups, and various kinds of disability and supposed inabilities among the groups were conflated. In common with other countries, early twentieth century eugenicists found much evidence linking feeble-mindedness, low school attainments, unemployment and criminality to a 'degenerate social class'. Lower class 'dull' women, especially if unmarried, 'threatened the racial stock by producing degenerate children' [22]. Teenage mothers, especially if single parents, have continued to be a target for condemnation, with a stress on the likely low 
achievements and possible unemployment or delinquency of their children.

Respondents in this study were well aware that the expanding testing and examination regimes from primary school onwards pressured schools and teachers to avoid labels of failing school, and also that raising qualification levels led to more students acquired failing labels. They were aware of the complex and confusing history of legislation and policy directed at those young people who did not achieve well in formal schooling and with the ever increasing categories and labels describing disabilities and special educational needs. There was a good deal of scepticism about the parental and even student claims made for resources, increasingly based on medical and psychological 'diagnosis'. In England in 1946 some 2\% of children were in some kind of segregated schooling with a further $8 \%$ regarded as low achievers in mainstream schools. Thirty years later the Warnock committee [23] claimed that some $20 \%$ of children were in need of special educational provision, $2 \%$ needing segregated special schools and $18 \%$ in mainstream. In 1984 Education Minister Keith Joseph was concerned that some $40 \%$ were lower attainers and set up a shortlived Lower Attainers Pupil Programme. By the 1990s some $3 \%$ of children had a Statement of special education need entitling them to special provision, with schools in different areas claiming that anything between $20 \%$ and $40 \%$ had learning and behavioural problems. All schools were to appoint a 'SENCO' (special educational needs co-ordinator).

In 2001 a Special Education and Disability Act and a code of practice attempted to define the responsibility of schools to cater for those with learning and behavioural difficulties and three categories were suggested. These were School Action, School Action Plus, where outside professional help would be sought, and a legally prescribed Statement entitling resources for a small number of students. By 2010 some 1.7 million children 5-16 were identified as having special educational need, $2.7 \%$ with Statements and $18.3 \%$ on school 'at risk' registers. As respondents noted, by this time both the Labour government and the incoming Coalition government were anxious about the cost of this provision and reforms were set in train. From 2014 an Education, Health and Care Plan will replace Statements and schools will be responsible for most students 'at risk'. As respondents pointed out, this will officially reduce numbers regarded as "having SEN" but dealing with large numbers of young people with learning and behavioural problems will place extra burdens on schools and increase their difficulties with parents, especially those demanding plans and resources. The heads and principals had various definitions of lower attainers: those not achieving the required five subjects in the secondary school examinations at 16 and/or those formally identified as having a special need or disability, and referred to anything between $20 \%$ and $40 \%$ of the population of young people who demonstrated learning or behavioural problems in schools or college. They all deplored the lack of good vocational courses for both pre- and post-16 lower attainers. As one head noted: "in school we try and educate as if everyone in the country was in the top $10 \%$ academically. But there is a huge majority who would like applied learning, there are practical and visual learners who are not going to sit in classrooms and be traditionally academic. We don't value applied skills and we squander talent." Schools and administrators were dubious about the expanding 'SEN industry' and increased parental pressure for a diagnosis and label that would bring resources. As one advisor noted "parents want a medical label: autism, Asperger's, ADHD, which absolves them of responsibility, there has been a medicalisation of behaviour". Other teachers noted that parents were receptive to their children having learning support but were reluctant to take responsibility for their behaviour.

\section{England: Vocational Education}

Historically, having large numbers of young people not in work or training has been a focus for economic and political anxiety about the social control of groups without work or income. In England the failure to provide good technical and vocational education has long been of concern, although technical schools set up after 1945 have gradually disappeared, as have most existing adult technical colleges. Local authorities initially had a duty to cater for young people post school, but until a recession in 1973 most school-leavers went untrained into employment or took apprenticeships that existed at the time. Even leavers from special schools were able to find work. Following on from this recession, the school-leaving age was raised to 16 and over the next forty years a plethora of schemes, programmes, commissions and committees concerned with vocational training for young people were set up, changed or abandoned, with responsibility for courses and funding constantly moved around between government departments. Administrators were familiar with the constant changes in funding responsibilities for youth training. Funding came back in 2011 with a Funding Agency responsible to the Department for Education although respondents from schools and colleges felt they were constantly attempting to 'jump through hoops' to please inspectors and government agencies. In 2009 former Education Minister Lord Kenneth Baker proposed a revival of technical schools and set up the first University Technical Colleges (UTCs) with cross-party support and extra money. These are intended for 14-19 year-olds studying technical subjects to higher levels, but respondents felt they would not address issues for the lower attainers. Governments in the 2000s were especially concerned with the million young people post- 16 who were not in education, employment or training, pejoratively labelled as 'NEETS' [24] although the Labour government decided that the 
official age for leaving education or training should be raised to 17 in 2013 and 18 by 2015 .

School and College personnel were concerned that a long series of suggestions for a unified curriculum for 14-19 year-olds continued to be ignored, resulting in most lower attaining students taking low wage employment, low-level College courses or joining the NEET group. Popular vocational courses studied both in schools, notably those offered from the 1990s by the Business and Technology Education Council (BTEC) were discouraged by the post 2010 Coalition government, which commissioned the Wolf Report [25], which claimed a third of young people 16-19 were on courses that offered no chance of progress into work and had little market value. This report did at least note that English vocational education is extraordinarily complex and opaque by European and International standards, and as respondents in the study pointed out, confusion remains over funding and responsibility for the education and vocational training for lower attainers and those regarded as having special needs or disabilities. The relatively small number of students with Statements of SEN are the responsibility of local authorities until age 25 , and they may remain in special school, progress to a college of further education or a specialist college, and in college it is the student's responsibility to declare their learning difficulty or disability. Governments from the early 1990s have attempted to revive apprenticeships and a National Apprenticeship Service was created in 2009. Respondents pointed out that higher level apprenticeships required good school qualifications, which were not achievable by lower attainers, although service and retail industries began to offer short apprenticeships, which were the subject of some criticism. College teachers pointed out that lower attainers could in any case spend time in salons and studios, practical and work experience, with entry level courses for those with more severe difficulties. A National College for disabled students aged 16-24 illustrated the need to study disability and vocational training together, as the students in wheelchairs were studying BTEC courses and acquiring jobs in retail, photography and selling ice rink tickets.

Common to all respondents in England was the understanding that although young people with physical and sensory disabilities could come from all social classes, the majority of low attaining students came from lower socio-economic homes, and acknowledgement that they were often dealing with poor families where employment was scarce or non-existent. They were also aware that if several generations were not in work and able to hand on a work ethic, this was likely to be caused by economic conditions rather than deficiencies in the families or the young people. The schools and colleges, however, were taking the task of socialising students into accepted norms and teaching social skills, which are demanded by employers seriously. They were concerned that government set an everchanging agenda, which had to be adhered to in order to obtain funds and satisfy inspections, and were aware that this required all courses, even those for students with learning difficulties and disabilities, to be credentialed and provide some sort of qualification. They were dubious whether, despite contacts with local employers, an expansion of qualifications would actually lead to employment, and viewed the removal of the 'equivalence' of vocational qualifications with academic courses as a backward step.

\section{The USA: Race and Lower Attainers}

The decentralised structure of the USA, where the Federal government sets a framework within which the 50 States function, but largely delegates educational control to States, local districts and school boards, offers a contrast to England where local authorities have progressively lost decision-making and funding powers. Nevertheless, the history and treatment of lower attainers and those falling within categories of special education is similar in the two countries. Compulsory attendance laws in the nineteenth century brought a variety of unwelcome children into the public school system-those from poor homes, the immigrant and foreign-born. "Truants, incorrigibles, cripples, the deaf, those with visual and speech defects, the feeble-minded and the moral delinquents" were all candidates for exclusion from schools or regular class ([26], p. 23). As in the UK, teachers were expected to credential children to required levels and those impeding this were likely to be removed from regular schooling. Class and race were markers in deciding who should be excluded or receive an inferior education, and education in the USA was strongly influenced by beliefs that racial minorities were likely to be less educable. A large literature continues to demonstrate that minorities-Black, Hispanic, and Native Americans in particular-are more likely to be considered lower attainers or in need of special education. As Blanchett noted "it is no secret that African-Americans and other students of colour, a disproportionate percentage of whom live in poverty and are educated in urban schools, have experienced educational inequality for decades, while their white peers have received a higher quality education" [27].

From the 1980s the labour market polarised more sharply into higher skilled and low skill, low-wage jobs and disadvantage by race in the job market continued. In 2011 some $8.5 \%$ of young white people were unemployed compared to $35.5 \%$ of African Americans and $15 \%$ of Hispanics. While Federal government and public anxieties during the cold war competition with the USSR from the 1960s led to demands to raise educational standards, current government, pressured by ideologies of a knowledge economy, has ensured that educating lower attainers is a large and expensive businesses for both Federal, State and private interests. In legislation similar to that in the UK, the Federal "No Child Left Behind" Act of 2001, required every State to 
develop standardized testing and accountability, and promote competition and 'choice' by giving the option of transferring to high-achieving schools, with failing schools being forced into becoming 'charter schools' or taken over privately [28]. Principals and teachers in the study felt that expectations from this act were unrealistic and opposition to the resulting high-stakes testing had developed. One result was that almost every school now offered special education services, with a continuum of placements in and out of mainstream schooling, although the 'Race to the Top' funding initiative, instigated by the Obama government in 2009, softened testing requirements somewhat. It is the norm in most states for students to stay in public or private school until 18 or 19 , apart from drop-outs, with expectations that all will progress, if possible, to a college course or find employment. In high schools, attention is given to the transition of lower attainers into some kind of vocational course with work experience, which will lead to some kind of post-school or College course and, in one school visited, students aged from 15 were on work placements in child care nurseries, restaurants and engineering works.

As in England, special education labels have proliferated, the 'learning disabled' label being most popular. Sleeter [29] argued that the category originally developed to allow middle class white parents to separate their children from working class and minority children, but now the majority of those with learning difficulties, minority and white, are described as learning disabled, and LD is now a crucial part of the US education system. As in other countries the medical and psychological professions continue to dominate the assessment of students who present a challenge to the education system, and 'disorders' such as ADHD, emotional disorders, autistic spectrum disorders, and conduct disorders are all candidates for medical and psychological intervention and make considerable profits for drug companies. The respondents were clear however, that whatever the 'brain capacities' or special needs of students, all must, if possible, be prepared for some kind of work, even if in the lower sectors of labour and pointed out that there are now a host of special education services, transition services, rehabilitation departments, occupational training centres and employment development centres, to assist those lower attainers or with specific disabilities to find work.

\section{Germany: Transition to Where?}

In the world economic crisis since 2008, the German economy has continued to function well and in the 'Eurozone crisis', which affected most EU countries, Germany played a leading role in attempting to stabilise other economies. Much of this performance was credited to a strong manufacturing sector, which benefited from the high level of skills of the workforce, trained in the dual system of apprenticeships in all industrial and commercial sectors, students spending time both with employers and at college. Until recently, it was possible to offer a majority of young people good vocational training. Now however, although there is less rhetoric about a knowledge economy than in other countries, there are an increasing number of lower attaining young people who cannot find a place in the dual system and are candidates for a transition system - "an unwanted and neglected part of vocational and education and training provision" ([30], p. 6; [31]). These young people, together with those who leave from the segregated special schools, are more likely to end up unemployed. While Germany retains its model of selective education after primary school, even the five former East German States opting for this rather than their previous comprehensive model, the country has been praised for its long history of attempting to equip almost all young people with training programmes that lead on to employment. Now, as respondents pointed out, an increasing number of young people are deemed unsuitable for the dual system, and some employers are reluctant to take on apprentices. A transition sector offering a variety of courses has developed, some of which may help students to progress but many programmes, as in England, keep students on courses with little possibility of progression [32].

On average in all States (Länder) the Gymnasium (academic school) takes around a third of children, with only $11 \%$ being from the working classes. The Realschule, whose students may go on to technical or higher skill training, takes another third, while the Hauptschule takes predominantly working class and minority students, especially Turkish and Kurdish. A few Länder have developed Gesamtschule (comprehensive schools) and around $6 \%$ of students are in segregated special schools, defended by a strong special teachers union. The respondents from schools and Berufskolleg [17] pointed out that it is the young people leaving the Hauptschule or special schools without a leaving certificate that are identified as lower attainers and likely to be in transition programmes. The government has recently been concerned that special school leavers have no certificate and the Federal Standing Conference of Ministers of Education and Cultural Affairs are currently discussing creating a certificate to make it easier for special school leavers to move to vocational courses. In one large Berufskolleg where $43.5 \%$ of students were in the dual system, $16 \%$ on college based apprenticeships and over $37 \%$ in transition programmes, staff noted that young people on lowerlevel programmes liked practical work, but had problems with literacy and numeracy. As in other countries the young people on these programmes were mainly from the working class and/or a minority background, many with parents not in work, and they were the ones most likely to drop out and remain unemployed. In one of the Hauptschulen visited, the students came from thirty countries, the majority Turkish, Kurdish and Iranian, and the principal noted the clear social class divide in the city with the Gymnasium taking 
around $40 \%$ of white middle class students. He pointed out the disadvantages his students faced, becoming more encapsulated in local areas and facing discrimination from employers, even after training courses. The respondents were clear however, that although the lower attainers were mainly from poor and disadvantaged homes, it was largely a shrinking labour market, low wages and the whole economy, that contributed to the disadvantage, rather than regarding the young people and their families as deficient.

\section{Malta: Colonial and Religious Legacies}

The small Mediterranean island of Malta functions with a centralised education system heavily influenced by a colonial legacy and the Catholic church. Party politics can be hostile, and in 2010 the Education Minister was accused by the Shadow Minister of "running education like a personal fiefdom" [33]. The school system has a long history of academic selection of students at eleven for the Lyceum or general secondary schools, despite sporadic attempts by the Labour Party to create comprehensive schools. As in England, technical schools developed post-1945 were gradually were closed down. The National Party, originally a strong supporter of selection, has a close relationship with the Church, which still influences the national curriculum in all schools, and around $25 \%$ of mainly middle class students are educated in church schools, with over $12 \%$ in private schools. A reorganisation from 2007 divided the island into ten areas, confusingly labelled as 'colleges' with each having a number of primary and secondary schools. Parents can notionally chose from these schools, however church and private schools not included in these areas. Special schools for children with disabilities were set up post 1945, but from 1989 the government promoted inclusive education with the aim of reducing numbers in special schools. As the current Director noted, a Student Services Department was set up in 2007 to oversee all special services, with managers appointed to deal with inclusive education, and more special resource centres and psychosocial services. Special schools were to be designated as Resource Centres. One respondent, the head of one of the four remaining special schools, was concerned that even the most severely disabled children should spent some time in mainstream school. As in other countries, official labels for a Statement for resources cover children with difficulties due to a 'physical, sensory, intellectual or psychological nature' [34], but the major anxieties centre round lower attainers in mainstream schools, disruptive students, anti-social behaviour and school drop-outs. Respondents noted the range of support services available-a school psychological service, education social work service, guidance and counselling, anti-substance abuse and others. In Malta the counselling services have been supplemented by what Darmanin [35] called 'love as an alternative discourse', by which lower class lower achieving students were offered affection and care in place of educational programmes, while middle class students were prepared for a competitive global economy. Those with learning and behaviour problems could be separated into Learning Centres, dubbed 'non-learning Centres' by some teachers.

Although currently the smallest country in the EU, Malta adopted the goals of free markets, belief in global competition and a knowledge economy, supposedly accompanied by flexible workers who would invest in their own human capital. As in the UK, Malta made assumptions that there is a skill shortage, rather than a shortage of jobs, and political ambitions were for the Island to become a knowledge economy by investing in, for example, ITC, micro-electronics, pharmaceuticals and other high value services [36]. The position of lower attainers in this economy was not remarked on, despite some $40 \%$ of young people leaving school at 16 with few qualifications. Respondents noted that the rising unemployment among early leavers was masked by those without qualifications leaving to work in family businesses. As in England, the government has been keen to revive apprenticeships and skill training in cooperation with employers, and from 2010 the Minister of Education announced that schools could study BTEC vocational programmes pre-16, at the time when the English Minister of Education was criticising the equivalence of vocational and academic courses. The main provider of all post 16 vocational education and training is the Malta College of Arts, Science and Technology (MCAST) set up in 2001, which is made up of nine institutes around the island, offering courses ranging from art and design to advanced marine engineering [37]. Within a National Qualification Framework there are eight levels of courses, from entry and foundation courses for lower attainers, to doctoral degrees. An aim of the College, as one respondent noted is to "get over to lower attainers that all can work" and those with learning difficulties or disabilities can contact an Inclusive Education Unit and a Learning Support Unit. While there is a growing realisation that all young people must be educated and trained for some kind of employment, a rhetoric of a knowledge economy precludes much planning for the employment of lower attainers.

\section{Finland: A Model for Us All?}

International comparative testing of student school performance has become accepted around the world since 1958, when a group of scholars, including several from Finland, developed an international test. The best known are the PISA tests, developed by the OECD for students aged 15 in reading, maths and science. The results of tests cause governments anxiety if their students go down in tests scores, and educational policy in a number of countries is influenced by PISA results [38]. Finland, regularly out-performing other countries, rapidly became a country where policy-makers and 
educationalists of all kinds visited to examine how the good results were achieved. One indisputable result is that in Finland, when PISA results are divided into percentiles of achievement, the lowest group of achievers do better than in any other country. Hautamäki and his colleagues, in an analysis of the 2006 PISA tests, noted that some students with functional disabilities were included in the Finnish sample [39]. Respondents pointed out with some pride that the country has an egalitarian assumption that all young people are to be valued whatever their learning difficulties, the school system is comprehensive, resources are good, and the teachers are highly trained. The declared aim by the Ministry of Education is to disrupt the transmission of inequalities between generations, and policies are designed to attempt this. Around $30 \%$ of children are offered what is described as special education, but is in essence additional help throughout the pre-school and school years to 19 and children do not have to wait to fail [40] before they are given additional educational support. Some $8 \%$ of students are regarded as having more severe problems and this number is a matter of concern for government and educationalists. However, as respondents pointed out, the special education can be given in or out of mainstream and in small classes, it does not negate the comprehensive principle and schools are not in competition for students as in England.

At 16 around $55 \%$ of young people progress to upper secondary school for an academic education, around $40 \%$ go on to vocational College and there are some apprenticeships for 16 year-olds, although most apprenticeships are taken by older workers. As in Germany and other Nordic countries, the vocational colleges are well-resourced and organised and prepare students for a trade or occupation, and there can be progression to degree level at a polytechnic college. Students can self-declare that they need special help in college, and the most popular 'need' is for help with literacy and numeracy-as in other countries, many students claiming the popular diagnosis of dyslexia. There are several vocational colleges for students with special educational needs and it is recognised that successful vocational preparation for "vulnerable groups in the society" [41] has still not been achieved. While the Finnish economy includes both industry, agriculture, service and a 'knowledge' economy, youth unemployment, as in other countries, continues to worry government. Although the language of social class is not much used, as in other countries-there is a difference in destination between those from middle and working class homes, although more attention is given to the congruence between education, vocational training and the labour market.

\section{Social Justice and Inclusion}

There are various ways in which the position of all those considered to be lower attainers or otherwise trouble- some to current education and training systems could be theorised. A political economic analysis could point out that the prevailing global pressures towards knowledge economies and a competitive global economy leads to the marginalisation and social control of those who will not or cannot participate in higher level education and skill training, but with resulting costs as these groups must be included in some way in current systems. The study in five countries suggested that those tasked with following politically inspired policies are doing their best in practice to carry out policies that they may be sceptical about. Respondents in all countries thought that the notion of a knowledge economy did not apply to the groups in question and that 'raised standards' and constant upskilling of qualifications did not automatically translate into improved national competitiveness. They took the view that those classed as lower attainers would continue to have a place in the economy if resources were spent on vocational training and economies geared to providing some kind of employment. As one respondent noted "nuclear reactors are built by semi-skilled labour, and pig breeding genetics mean bigger pigs to be cared for by farm workers". There was also agreement that many of the service jobs lower attainers carry out should be properly waged and respected. The study suggested that countries such as Germany and Finland, which do attempt to provide coherent education and training to fit the economy, even if this is now proving more difficult, have a stronger economy and are better for the young people than the neo-liberal countries, which have more haphazard vocational programmes and relations with employers, and tend to regard lower attaining, troublesome, and/or disabled young people and their families as the problem rather than the economy.

A social justice analysis of what is happening could then move on to consider Rawls' view of what is just or unjust. To Rawls, the primary subject of justice is the way in which major social institutions-political, economic and social-distribute rights and duties. He noted that prevailing social structures are built on deep inequalities which affect life chances, but could not possibly be justified by an appeal to notions of merit or desert [42]. The justice of any social arrangements depends on how the economic opportunities and resulting social conditions in a society are distributed. While Rawls' work is of a higher level of abstraction than the familiar notions of a social contract, those countries committed to neo-liberal free-market economies are more likely to be violating this contract by their treatment of large sections of their population, especially those groups regarded as unable to attain higher levels of education or skills. Social injustices are renewed if affluent countries are not able or willing to make arrangements which include all young people in their education and training systems, and their labour markets. 


\section{References and Notes}

1. The OECD organises and administers the Programme for International Student Assessment (PISA) and has sponsored and carried out numerous studies on the transition from school to work, and youth employment. In 2005 the organisation recorded that "European leaders have set the goal for Europe to become the number one knowledge economy with a radical transformation of the economy and modernized social and economic education systems" In: OECD. Education at a Glance. Paris, France: OECD; 2005.

2. In 2010 European Commission President Barroso highlighted education and training as part of the Commission's strategy for over-coming the economic crisis. The Commission's "2020 Strategy" stressed growth based on knowledge, and inclusive societies.

3. Following a World Conference in Tontine, Thailand in 1990 on "Education for All", a Statement from a World Conference on Special Needs Education in Salamanca, Spain, in 1994 became the reference point for "inclusive education", a concept that has become increasingly contested over the years.

4. Slee R. The Irregular school: Exclusion, schooling and inclusive education. London, UK: Routledge; 2011.

5. Gautie J, Schmitt J, editors. Low-wage work in a wealthy world. New York, NY, USA: Russell Sage Foundation; 2010.

6. Lloyd C, Mason G, Mayhew K, editors. Lowwage work in the United Kingdom. New York, NY, USA: Russell Sage Foundation; 2008.

7. Tomlinson S. Ignorant Yobs? Lower attainers in a global knowledge economy. London, UK and New York, NY, USA: Routledge; 2013.

8. Further education colleges in England take students from age 14, although up to 2013 the school leaving age was 16 .

9. Green A. Education and State Formation. New York, NY, USA: St Martins Press; 1990.

10. Judt T. Post-War: A history of Europe since 1945. London, UK: Vintage; 2005.

11. Miller-Idriss $C$. Challenges and Changes in the German vocational system since 1990 . Oxford Review of Education. 2002;28(4):473-490.

12. Vlaeminke M. The subordination of technical education in secondary schooling 1870-1939. In: Summerfield $P$, Evans EJ, editors. Technical Education and the State since 1850. Manchester, UK: Manchester University Press; 1990.

13. DfE. The Importance of Teaching. London, UK: Department for Education; 2010.

14. Dorling D. Injustice. Bristol, UK: Policy Press; 2010.

15. Owen J. Chavs: The demonisation of the working classes. London, UK: Verso; 2011.

16. Tomlinson S. The irresistible rise of the SEN industry. Oxford Review of Education. 2012;38(3):267283.
17. In England the term college refers to some 222 colleges of further education offering academic and vocational courses from post-14 to adults of any age, plus 94 sixth form colleges and around 30 specialist colleges. They are separate from higher education but may offer university foundation courses. In the USA the term college predominantly refers to higher education, with two and four year courses offered at community colleges, and some states include technical and vocational colleges. In Malta mainly vocational and technical courses are offered at the Malta College of Arts, Science and Technology. In Germany the Berufskolleg offers vocational courses at all levels, and in Finland at upper secondary level students not aiming for university attend vocational college and there are also special vocational colleges.

18. The English National Council for Special Education commissioned a report (Continuum of Education Provision for children with special educational needs. Meath, Ireland; 2013) which overviewed 55 countries and concluded that there was much confusion and contradiction in definitions and categories of special need, and of inclusive practices.

19. Esping-Anderson G. Rethinking the Welfare State. In: Pearce N, Margo J, editors. Politics for a new generation. London, UK: Palgrave-Macmillan; 2007.

20. The term 'discussion' rather than 'semi-structured interview' was chosen to illustrate that the three questions introduced were intended to stimulate discussion rather than provide immediate answers to complex issues. Thus, the information was not amenable to coding.

21. Rawls J. A Theory of Justice. Cambridge, MA, USA: Harvard University Press; 1971.

22. Report of the Royal Commission on the Care and Control of the Feeble-minded. London, UK: HMSO; 1908.

23. DES. Special Educational Needs (The Warnock Report). London, UK: HMSO; 1978.

24. House of Commons Children, Schools and Families Committee. Young people not in education, employment or training. 8th report. London, UK: The Stationary Office; 2010.

25. Wolf A. A Review of Vocational Qualifications. London, UK: DfE; 2011.

26. Lazarson M. The origins of special education. In: Chambers JG, Hartman WT, editors. Special education policies: Their history, implementation and finance. Philadelphia, PA, USA: Temple University Press; 1983.

27. Blanchett WJ. Foreword: Educational inequities: The intersection of disability, race and class. In: Connor DJ, editor. Urban narratives: Portraits in progress. New York, NY, USA: Peter Lang; 2008.

28. Hursh $D$. The growth of high-stakes testing in the USA: Accountability, markets and the decline of educational equality. British Educational Research Journal. 2005;31(5):605-622.

29. Sleeter CE. Learning Disabilities: The social construction of a special education category. Exceptional Children. 1986;53(1):46-54. 
30. Ertl H. After the dual system: Notes on aspects of German skills policy SKOPE public policy forum. Oxford, UK: University of Oxford; 2009.

31. Ertl H. Tradition and reform: Modernising the German dual system of vocational education. In: Hayward $\mathrm{G}$, James $\mathrm{S}$, editors. Balancing the skills equation Bristol, UK: Policy Press; 2004.

32. Higham J, Kremer H, Yeomans D. Exploring intermediate vocational education and training for 1619 year-olds in Germany and England. European Education Research Conference, Vienna, Austria; 2009.

33. Bartolo E. Meet Minister Dolores Potyomkin in education (partly). Malta Today; 7 March 2010.

34. Ministry of Education, Culture and Sport. Special School Reform. Valletta, Malta: Department of Student Services; 2009.

35. Darmanin M. When students are failed: 'Love' as an alternative educational discourse. International Studies in the Sociology of Education. 2003;13(2): 141-170.

36. Central Bank of Malta. Malta's economy and the path to the euro. Valletta, Malta; 2006.

37. Grech M. A Message from the Principal, Professor Maurice Grech. MCAST Prospectus. Malta; 2010-2011.

38. Meyer H-D, Benavor A. PISA, Power and Policy: The emergence of global educational governance. Oxford, UK: Symposium Books; 2013.

39. Hautamäki J, Harjunen E, Hautamäki E, Karjalainen T, Kupainen T. PISA 2006: Finland. Helsinki, Finland: Ministry of Education; 2009.

40. Graham J, Jahnukainen M. Wherefore art thou inclusion? Analysing the development of inclusive education in New South Wales, Alberta and Finland. Journal of Educational Policy. 2011;26(2):263-278.

41. Sabel C, Saxenian A, Miettinen R, Kristensen P $H$, Hautamäki J. Individualised service provision in the new welfare state: Lessons from special education in Finland. Helsinki, Finland: SITRA University of Helsinki; 2010.

42. Rawls J. Theory of Justice. Revised edition. Cambridge, MA, USA: Harvard University Press; 1999. 


\section{Appendix}

\section{England}

Local authorities are responsible for assessment subject to national guidelines.

Moderate learning difficulty. Behaviour, emotional and social difficulty. Specific learning difficulty. Speech, language and communication needs. Autistic spectrum disorder. Severe learning difficulty. Physical disability. Hearing impairment. Visual impairment. Profound and multiple disability. Multisensory impairment. Other disability.

\section{$\underline{\text { USA }}$}

Speech and language impairments. Emotionally disturbed. Gifted and talented. Specific learning disabilities (LD). Mental retardation. Autism. Visual impairment. Hearing impairment. Orthopaedic impairment. Other health impairment. Multiple disability and traumatic brain injury.

\section{Germany}

Learning disability. Emotional and social development. Mental development. Bodily and motor development. Health problems. Speech problems. Speech and sight problems. Multiple and unclassified.

\section{Malta}

Intellectual disability. Specific learning difficulty. Emotional and behavioural difficulty. Sensory difficulty. Physical disability. Multiple disability. Labels such as autism, dyslexia, and ADHD (attention deficit and hyperactivity disorder) are used.

\section{Finland}

'Diagnostic' labels rarely used. From pre-school children's development is monitored and they are offered support. Language and communication development, physical disability, and developmental delay are helped. Unofficial labels are used, dyslexia being the most common.

In all countries using SEN categories a majority of young people are assessed as having learning and behavioural problems, which merge with those not categorised but regarded as problems in schools. 